\title{
PEMANFAATAN LIMBAH HASIL PENGOLAHAN SUMBER DAYA ALAM PESISIR UNTUK MENINGKATKAN PENDAPATAN MASYARAKAT SEKITAR HUTAN MANGROVE PANGKAL BABU
}

\author{
Rike Puspitasari T, Asrizal Paiman, Eva Achmad, Fazriyas dan Riana Anggraini \\ Dosen Fakultas Kehutanan Universitas Jambi \\ Kampus Pinang-Masak, Mendalo Indah 36361 \\ e-mail : rikepuspitasari_unja@yahoo.co.id; malano_57@yahoo.co.id; \\ evaachmad@unja.ac.id; fazriyasjbi@yahoo.com;nanuk_onra@yahoo.co.id
}

\begin{abstract}
ABSTRAK
Salah satu sentra pengahasil kelapa di Kabupaten Tanjung Jabung Barat adalah di Dusun Bahagia, Desa Tungkal I, Kecamatan Tungkal Ilir. Di Desa Tungkal I khususnya di Dusun Bahagia, sebagaian besar masyarakatnya berprofesi sebagai petani kelapa. Besarnya potensi kelapa yang dihasilkan, membuat limbah batok dan sabut kelapa tersedia melimpah dan belum dimanfaatkan secara maksimal. Limbah kelapa ini bisa diolah melalui teknologi sederhana menjadi produk briket arang dan cocopeat, sehingga diharapkan bisa menjadi salah satu tambahan kegiatan dan penghasilan dari masyarakat sekitar hutan mangrove Pangkal Babu. Kegiatan pengabdian ini diberikan kepada dua mitra yaitu kelompok tani bakau lestari dan kelompok tani wanita RT.08 Dusun Bahagia. Metode yang digunakan yaitu penyuluhan, demonstrasi, praktek dan evaluasi. Dari hasil kegiatan mitra telah memahami manfaat dari briket arang dan cocopeat serta mitra sudah terampil mengolah limbah batok dan sabut kelapa ini menjadi briket arang dan cocopeat. Kuantitas dan kualitas briket arang dan cocopeat yang dihasilkan masih perlu ditingkatkan lagi agar dapat meningkatkan perekonomian dan pendapatan rumah tangga mitra.
\end{abstract}

\section{Kata kunci : Limbah Kelapa, Briket Arang, Cocopeat}

\section{PENDAHULUAN}

\section{Analisis Situasi}

Kabupaten Tanjung Jabung Barat mempunyai luas areal perkebunan seluas 171.333,6 Ha yang meliputi beberapa komoditi perkebunan yaitu kelapa sawit, karet, kelapa, kopi dan pinang (Bangun, 2017). Untuk komoditi kelapa sendiri Kabupaten Tanjung Jabung Barat memiliki luas tanaman menghasilkan seluas 38.546 Ha dengan produktivitas sebesar 50.494 ton dan produktivitas per hektarnya sebesar 1,2 ton/ha (Statistik Perkebunan, 2013 dalam Kemala, 2015). Salah satu sentra pengahasil kelapa di Kabupaten Tanjung Jabung Barat adalah di Dusun Bahagia Desa Tungkal I Kecamatan Tungkal Ilir. Di Desa Tungkal I khususnya di Dusun Bahagia, sebagaian besar masyarakatnya berprofesi sebagai petani kelapa hal ini dapat dilihat disepanjang kanan kiri jalannya banyak kita kebun kelapa (Gambar 1.A) dimana buah kelapa tersebut umumnya diolah oleh petani untuk dijadikan kopra (Gambar 1.B). 


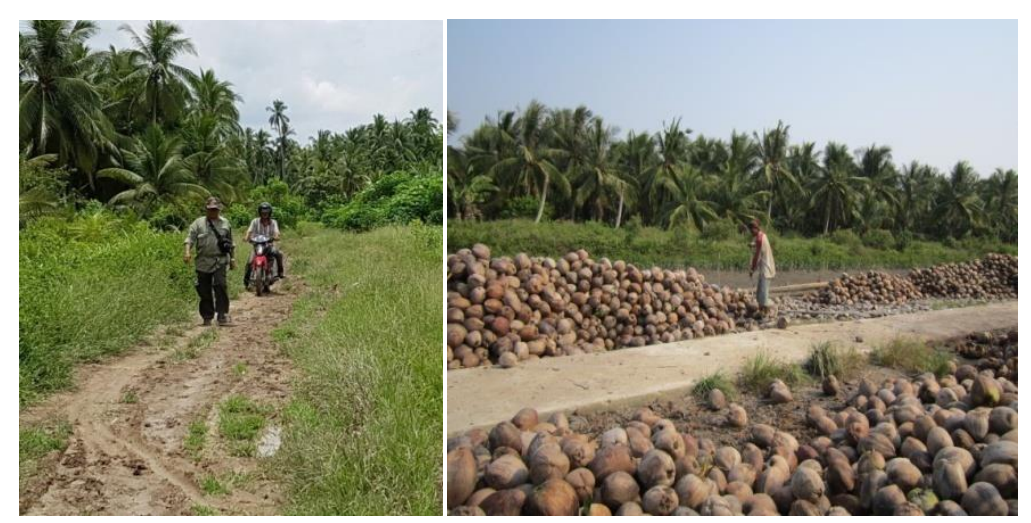

Sumber foto : Dokumen Pribadi

A

B

Gambar 1. Potensi Kelapa di Dusun Bahagia Desa Tungkal I

Besarnya potensi kelapa di Dusun Bahagia selama ini masyarakat hanya memanfaatkan buahnya saja yaitu untuk dijadikan kopra. Pada tahun 2016, tim pengabdian kepada masyarakat Fakultas Kehutanan Universitas Jambi telah memberikan penyuluhan, demonstrasi dan pelatihan pengolahan kelapa untuk dijadikan VCO (Virgin Coconut Oil) sebagai alternatif pengolahan buah kelapa selain dijadikan kopra untuk meningkatkan nilai jual buah kelapa dan sumber pendapatan tambahan masyarakat di Dusun Bahagia. Selama ini, petani kelapa di Dusun Bahagia kurang memanfaatkan potensi limbah dari kelapa berupa tempurung kelapa dan sabut kelapanya. Masyarakat hanya menggunakan sabut kelapa untuk dijadikan benteng yang disusun di parit-parit depan rumah mereka mencegah banjir dan tempurung kelapanya mereka jadikan bahan bakar untuk memasak dalam skala kebutuhan rumah tangga. Hal ini menyebabkan limbah kelapa tersebut kurang termanfaatkan secara ekonomis.

Potensi limbah kelapa sendiri memiliki prospek yang cukup besar untuk bisa dimanfaatkan dan memiliki harga jual yang baik di pasaran dengan menjadikan limbah sabut kelapa tersebut menjadi cocopeat dan limbah tempurung kelapa menjadi briket arang. Cocopeat merupakan media tanam yang dibuat dari sabut kelapa. Dengan teknologi pengolahan limbah kelapa yang akan diberikan kepada kedua mitra yang terlibat maka diharapkan produk yang dihasilkan dapat meningkatkan pendapatan dari masyarakat Dusun Bahagia dimana hasilnya akan dipasarkan melalui koperasi Silva Bahagia yang telah terbentuk di tahun 2015 atas inisiasi tim pengabdian kepada masyarakat Fakultas Kehutanan Universitas Jambi.

\section{Permasalahan Mitra}

Berdasarkan komunikasi terkait antara tim pengabdian kepada masyarakat Fakultas Kehutanan Universitas Jambi dengan masyarakat Pangkal Babu Dusun Bahagia Desa Tungkal I dan kedua mitra yang terlibat didapatkan informasi bahwa selama ini masyarakat Dusun Bahagia khususnya petani kelapa, hanya memanfaatkan buah kelapanya saja untuk dijadikan kopra. Permasalahan yang muncul saat ini adalah mitra belum mengetahui dan memahami manfaat-manfaat apa saja yang bisa dihasilkan dari limbah sabut kelapa dan tempurung kelapa. Mitra belum mengetahui dan memahami teknologi sederhana yang bisa digunakan untuk pengolahan limbah kelapa tersebut menjadi suatu barang yang bernilai ekonomis tinggi. 
Mitra juga belum mengetahui pangsa pasar dari hasil pengolahan limbah sabut dan tempurung kelapa tersebut yang dapat meningkatkan perekonomian keluarga mitra yang dimaksud.

\section{TARGET DAN LUARAN}

Kegiatan pengabdian ini ditargetkan akan lebih meningkatkan pemahaman, pengetahuan, dan ketrampilan masyarakat Dusun Bahagia pada umumnya dan kedua mitra khususnya dalam pengolahan limbah sabut kelapa dan tempurung kelapa sehingga masyarakat dan kedua mitra dapat meningkatkan pendapatan dan perekonomian mereka tanpa mengambil hasil hutan mangrove di sekitar mereka.

\section{METODE PELAKSANAAN}

\section{Tempat dan Waktu}

Kegiatan pengabdian kepada masyarakat ini dilaksanakan di Dusun Bahagia Desa Tungkal I Kecamatan Tungkal Ilir Kabupaten Tanjung Jabung Barat dengan 2 (dua) mitra yang terlibat yaitu kelompok tani bakau lestari dan kelompok tani wanita Dusun Bahagia RT.08. Waktu kegiatan dimulai sejak persiapan selama 6 (enam) bulan.

\section{Bahan dan Alat}

Bahan yang digunakan dalam kegiatan pengabdian ini adalah arang tempurung kelapa, sabut kelapa, tepung kanji, minyak tanah, lilin, dan air. Sedangkan alat-alat yang digunakan adalah paralon atau bambu pencetak, kayu pemukul atau pengempa, drum pengarangan, panci pemasak 3 liter, kompor, tabung gas, alas terpal, wadah, timbangan, kasa besi, karung, palu besi, kamera, liquid crystal display (LCD), ayakan, lesung, parang, pulpen, note book,

\section{Penyuluhan}

Kegiatan pengabdian ini bertujuan untuk memberikan pemahaman akan manfaat yang bisa diperoleh dari pengolahan limbah kelapa berupa sabut dan tempurung menggunakan teknologi sederhana untuk dijadikan cocopeat dan briket arang. Penyuluhan dilakukan dengan mempresentasikan materi penyuluhan yang dibuat dalam bentuk power point kepada kedua mitra secara bersamaan. Setelah presentasi dilakukan diskusi dua arah secara informal dan kekeluargaan guna menciptakan sambung rasa atau keakraban antara dua mitra dengan tim pengabdian. Di kegiatan penyuluhan ini juga akan dijelaskan, bagaimana prospek pemasaran dari produk cocopeat dan briket arang yang akan dihasilkan oleh kedua mitra dalam upaya meningkatkan perekonomian anggota keluarga mitra pada khususnya dan masyarakat Dusun Bahagia pada umumnya sehingga masyarakat tidak harus mengambil hasil hutan mangrove yang berbatasan langsung dengan tempat tinggal mereka.

\section{Demonstrasi dan Pelatihan}

Setelah kegiatan penyuluhan dilakukan, kegiatan selanjutnya adalah demonstrasi dan pelatihan. Kegiatan demonstrasi dan pelatihan dilakukan sebanyak dua kali kegiatan yang terdiri atas :

\section{Demonstrasi dan Pelatihan Pembuatan Briket Arang}

Kegiatan demonstrasi dan pelatihan pembuatan briket arang ini akan diberikan kepada kedua mitra dengan menggunakan alat-alat dan teknologi sederhana dengan tujuan agar kedua mitra dapat dengan mudah dalam menerima materi pelatihan dan dapat menggunakan 
teknologi tersebut dengan baik. Adapun tahapan pembuatan briket arang yang akan diberikan oleh tim pengabdian kepada kedua mitra.

\section{Demonstrasi dan Pelatihan Pembuatan Cocopeat}

Kegiatan demonstrasi dan pelatihan pembuatan cocopeat ini akan diberikan kepada kedua mitra dengan menggunakan alat-alat dan teknologi sederhana dengan tujuan agar kedua mitra dapat dengan mudah dalam menerima materi pelatihan dan dapat menggunakan teknologi tersebut dengan baik. Cocopeat dari sabut kelapa dimanfaatkan sebagai media tanam, karena mampu menahan unsur kimia dari pupuk maupun kandungan air bahkan mampu menetralkan kondisi keasaman tanah, sehingga, cocopeat sangat baik digunakan untuk media tanam.

\section{Evaluasi}

Setelah kegiatan penyuluhan, demonstrasi dan pelatihan selesai dilakukan, kedua mitra diminta untuk melakukan pembuatan briket arang dan cocopeat secara mandiri. Setelah itu, tim pengabdian kepada masyarakat akan melakukan evaluasi terhadap kedua produk yang dihasilkan oleh secara mandiri kedua mitra. Dalam kegaiatan evaluasi ini akan dilihat bagaimana tingkat keberhasilan pembuatan kedua produk oleh kedua mitra, hambatan dan kendala yang dialami oleh kedua mitra, kuantitas dan kualitas produk yang dihasilkan oleh kedua mitra. Dalam kegiatan evaluasi ini juga, mitra akan diberikan pelatihan dalam hal mengemas produk briket arang dan cocopeat untuk dipasarkan bersama melalui koperasi "Silva Bahagia" yang terlah berdiri pada tahun 2015 dan dibantu dengan Fakultas Kehutanan Universitas Jambi sebagai pembina.

\section{HASIL DAN PEMBAHASAN}

Kegiatan pengabdian kepada masyarakat ini dilakukan kepada 2 mitra yaitu kelompok tani bakau lestari dan kelompok tani wanita RT.08 Dusun Bahagia. Kegiatan pengabdian kepada masyarakat ini terdiri dari beberapa kegiatan, antara lain :

Pengurusan izin kegiatan pengabdian kepada masyarakat

Pengurusan izin kegiatan pengabdian ini dilakukan kepada kedua mitra terkait untuk mendapatkan izin dari pihak terkait, untuk mengatur jadwal setiap tahapan kegiatan yang akan dilakukan karena harus menyesuaikan jadwal tim pengabdian kepada masyarakat dan anggota kelompok tani, serta menyiapkan bahan baku yang akan digunakan untuk kegiatan pengabdian kepada masyarakat seperti batok kelapa dan sabut kelapa.

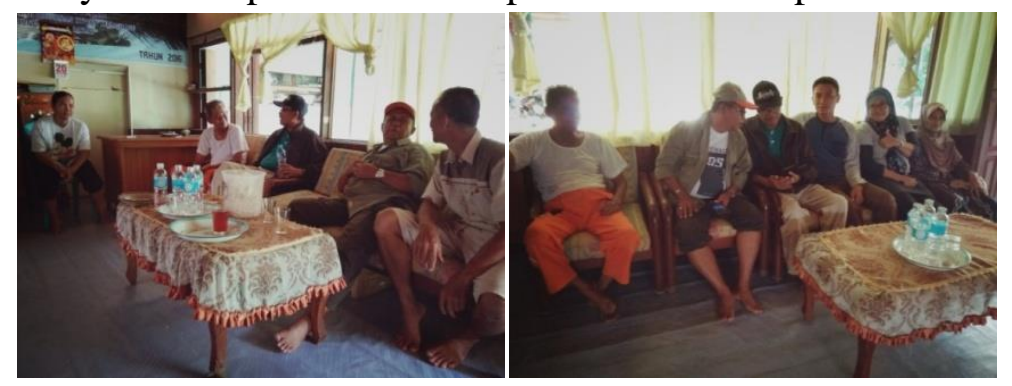

Gambar 2.Pengurusan Izin dan Persiapan Pengabdian Kepada Masyarakat Ke- Dua Mitra Terkait

Kegiatan dilanjutkan dengan mengecek ke lokasi dimana limbah kelapa seperti sabut dan batok kelapa tersedia dalam jumlah melimpah yang akan digunakan sebagai bahan baku 
utama untuk kegiatan pengabdian kepada masyarakat ini. Lokasi tersebut tidak jauh dari rumah kelompok tani bakau lestari dan kelompok tani wanita RT.08 Dusun Bahagia.

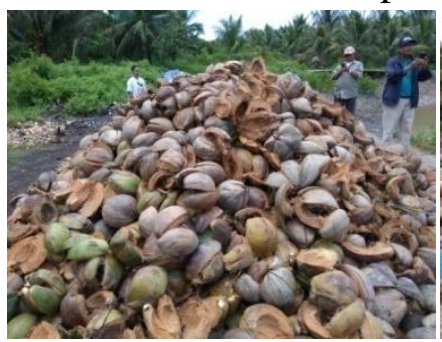

a

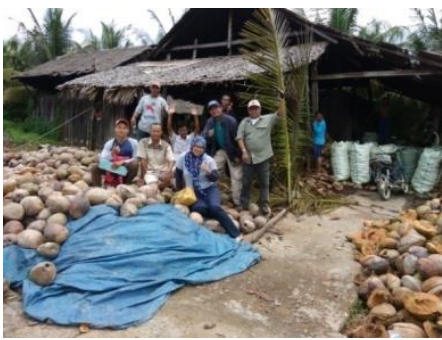

b

Gambar 3. (a)Limbah kelapa; (b) Tim Pengabdian di Lokasi Pengumpulan Limbah Kelapa

\section{Penyuluhan pembuatan briket arang}

Pada kegiatan penyuluhan ini tim pengabdian memberikan materi tentang pengenalan briket arang, kegunaan dari briket arang, alat dan bahan yang digunakan dalm briket arang dan bagaimana prospek pasar dari penjualan briket arang tersebut. Anggota Kelompok tani sangat antusias di dalam kegiatan penyuluhan ini. Kegiatan ini dilakukan secara bersamaan terhadap kedua mitra yaitu kelompok tani bakau lestari dan kelompok tani wanita RT.08 Dusun Bahagia. Kegiatan penyuluhan ini berlangsung secara kekeluargaan sekaligus meningkatkan rasa kekeluargaan.

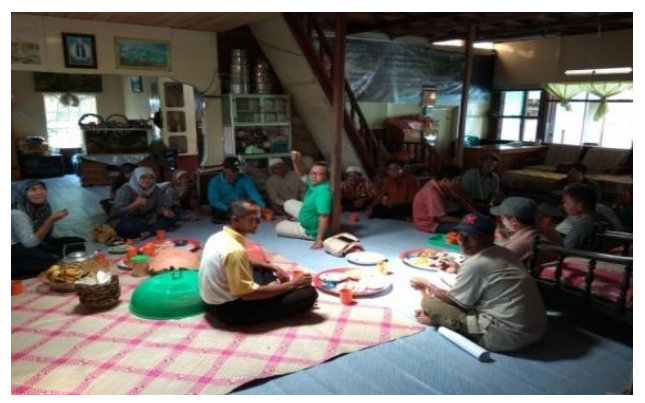

Gambar 4. Suasana Keakraban Saat Kegiatan Penyuluhan

Pembuatan Briket Arang

2. Demonstrasi dan praktek pembuatan briket arang

Kegiatan Demonstrasi dan praktek pembuatan briket arang ini terdiri dari beberapa tahapan kegiatan, yaitu :

a. Pengenalan bahan dan alat pembuatan briket arang

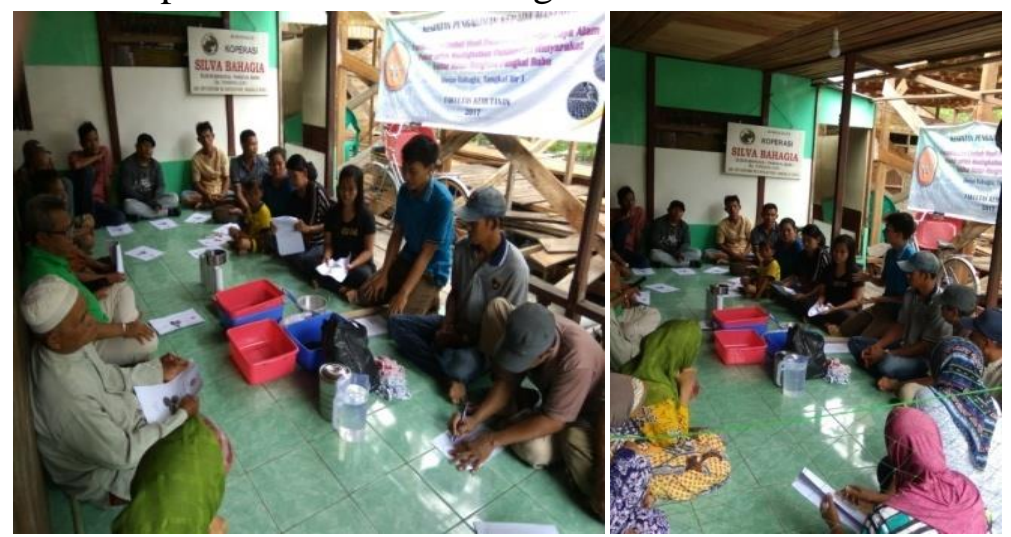

Gambar 5. Pengenalan Bahan dan Alat Pembuatan Briket Arang 
b. Demonstrasi Pembuatan Bahan Baku Arang Menjadi Ukuran Yang Sama

Pada Kegiatan ini ini diajarkan bagaimana membuat bahan baku arang baik arang yang terbuat dari batok maupun sabut kelapa menjadi ukuran yang sama dengan cara menghancurkannya menggunakan palu dan menyaringnya menggunakan saringan yag telah dibuat dari kawat kasa.

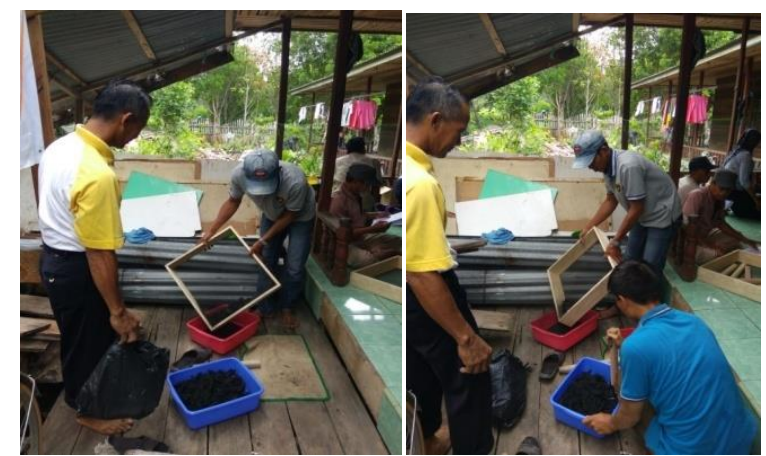

Gambar 6. Demonstrasi Pembuatan Bahan Baku Briket Arang

c. Pembuatan Bahan Perekat

Bahan perekat dibuat dari tepung sagu dicampur dengan air dengan perbandingan $1: 3$ kemudian dimasak/dipanaskan sampai mengental dan berwarna bening.

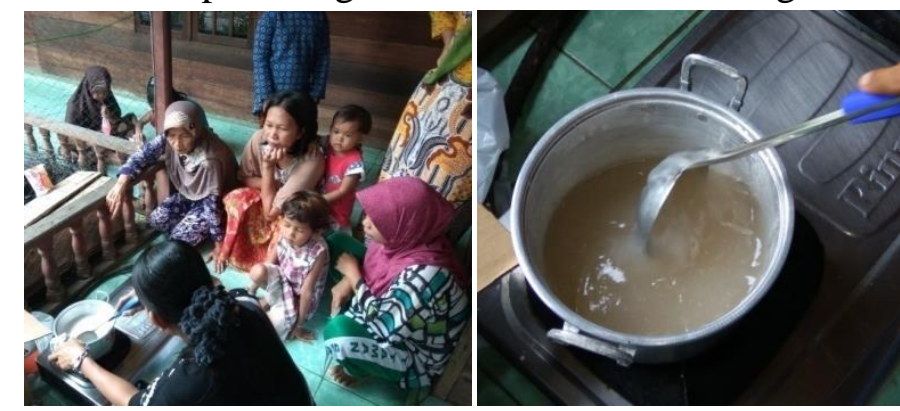

Gambar 7. Proses Pembuatan Bahan Perekat

d. Pencampuran Bahan Baku Briket Arang Dengan Bahan Perekat

Pencampuran bahan baku briket arang yang berupa arang batok dan arang sabut kelapa dengan bahan perekat dilakukan dengan perbandingan $1: 10$.

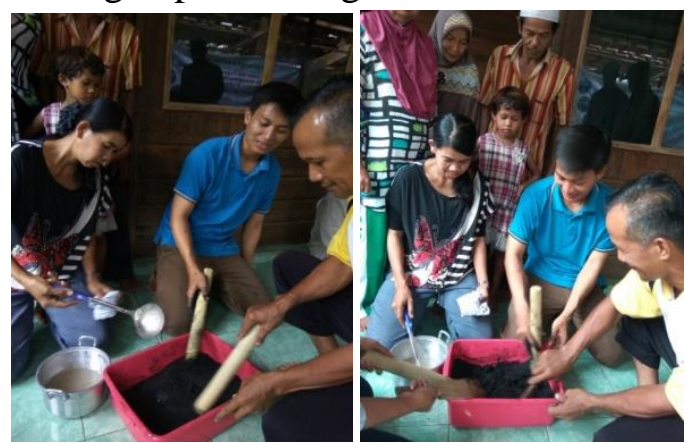

Gambar 8. Pencampuran Bahan Arang dan Bahan Perekat 


\section{e. Pencetakan Briket Arang}

Proses pencetakan briket arang dilakukan menggunakan alat sederhana berupa pipa paralon, tongkat kayu dan alas dari triplek. Ukuran briket arang yang dicetak disesuaikan dengan kebutuhan dan keinginan masing-masing anggota kelompok tani.

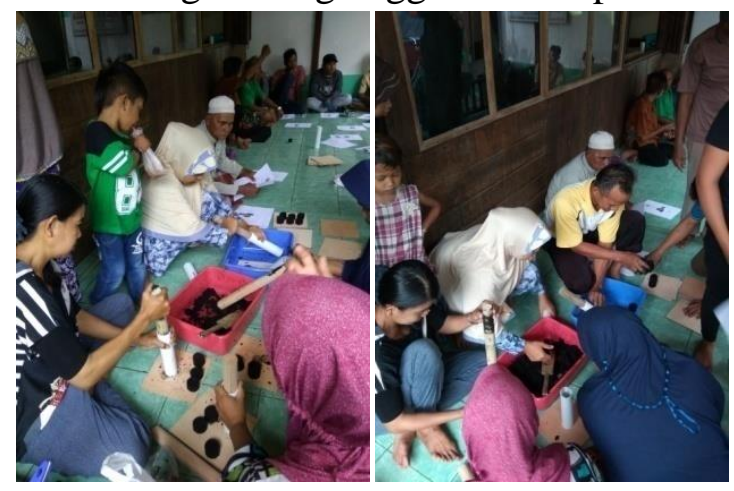

Gambar 9. Proses Pencetakan Briket Arang

\section{f. Proses Uji Coba Memasak Menggunakan Briket Arang}

Uji coba memasak menggunakian briket arang dilakukan menggunakan briket arang yang dibawa oleh tim pengabdian karena hasil briket arang yang dibuat oleh anggota kelompok tani belum dilakukan proses pengeringan dengan cara di jemur. Uji coba memasak ini dilakukan dengan merebus telur.

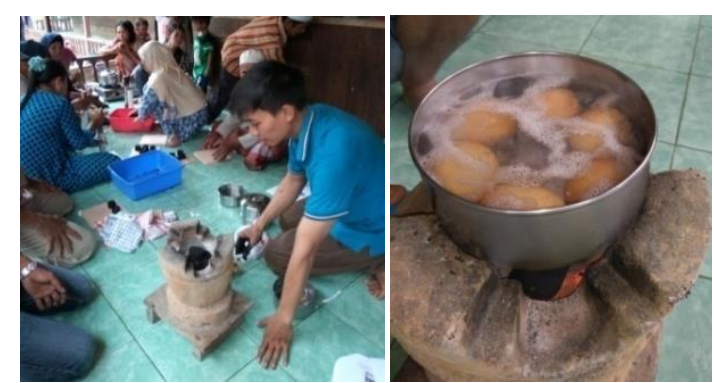

Gambar 10. Memasak Telur Menggunakan Briket Arang

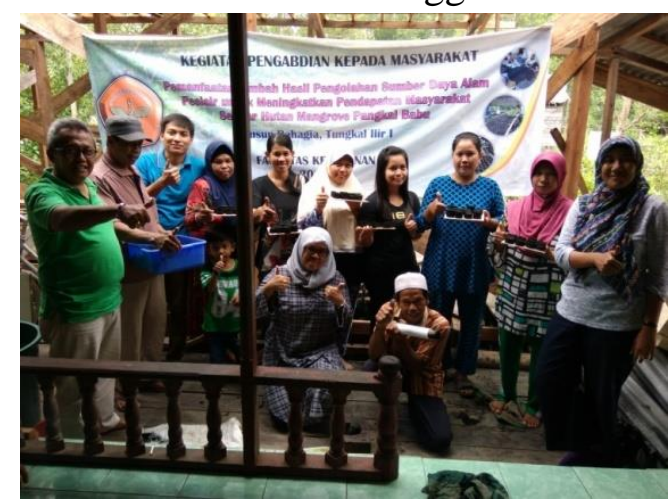

Gambar 11. Bersama Anggota Kelompok Tani dan Hasil Briket Arang yang Dibuat.

Setelah kegiatan demonstrasi dan praktek pembuatan briket arang dilakukan, kemudian dilakukan sesi foto bersama dengan anggota kelompok tani bersama hasil briket arang yang dibuat oleh masing-masing anggota kelompok tani. Pada akhir kegiatan demonstrasi dan praktek pembuatan briket arang ini, juga dilakukan penyerahan secara simbolis melalui perwakilan anggota kelompok tani alat sederhana pembuatan briket arang. 


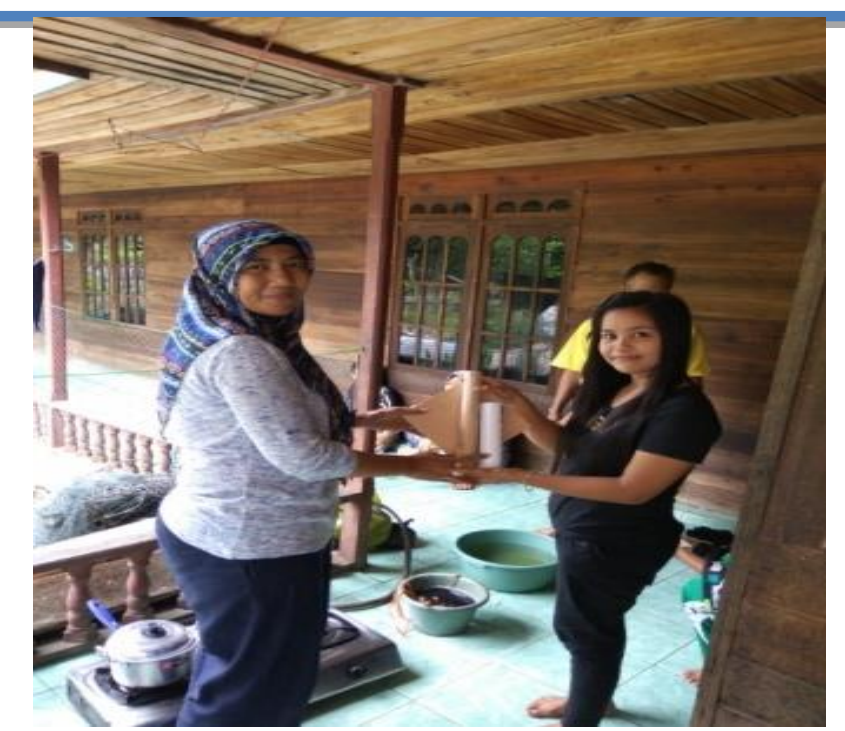

Gambar 12. Penyerahan Secara Simbolis Alat Sederhana Pembuatan Briket Arang ke Anggota kelompok Tani

\section{Penyuluhan pembuatan cocopeat}

Kegiatan penyuluhan pembuatan cocopeat ini dilakukan kepada dua mitra yaitu kelompok tani bakau lestari dan kelompok tani waanita RT.05 Dusun Bahagia. Pada kegiatan penyuluhan ini diberikan materi tentang teknologi sederhana yang cara membuat cocopeat yang bisa digunakan sebagai media tanam. Kegiatan penyuluhan dilakukan secara kekeluargaan dan kelompok tani secara aktif dan bersemangat mengikuti kegiatan penyuluhan ini. Kegiatan ini diisi juga dengan sesi tanya jawab, bertukar pikiran, membahas perbedaan hasil dari cocopeat yang dibuat dengan teknologi sederhana (manuall) dan teknologi modern (mesin).
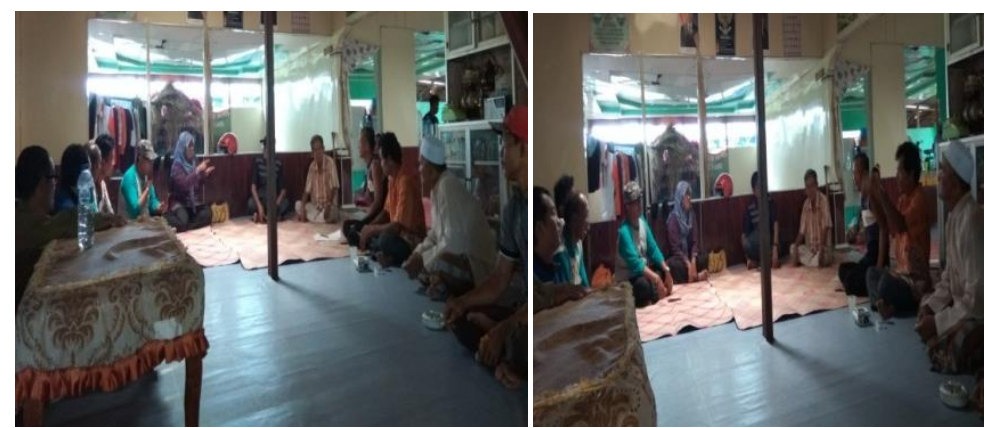

Gambar 13. Penyuluhan Pembuatan Cocopeat

\section{Demonstrasi dan Praktek Pembuatan Cocopeat}

Demonstrasi dan praktek pembuatan cocopeat dilakukan kepada dua mitra yaitu kelompok tani bakau lestari dan kelompok tani waanita RT.05 Dusun Bahagia. Demontrasi dan praktek ini dilakukan dengan menggunakian teknologi yang sederhana sehingga bisa diaplikasikan oleh seluruh anggota kelompok tani. 


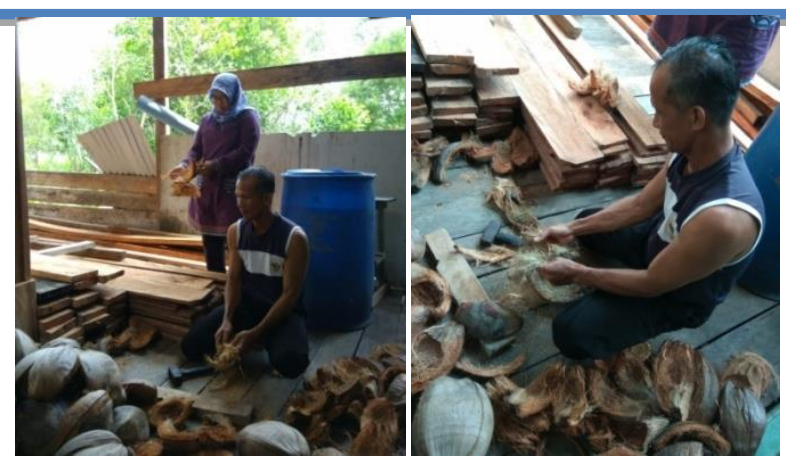

Gambar 14. Praktek Pembuatan Cocopeat

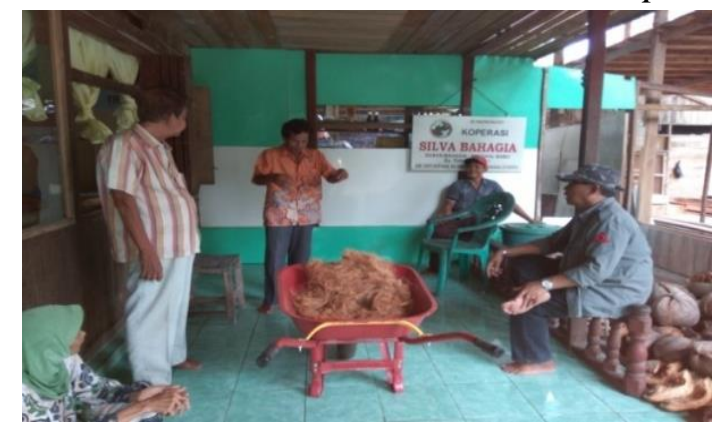

Gambar 15. Berdiskusi dengan Anggota Kelompok Tani terhadap Hasil Cocopeat yang Telah Dibuat

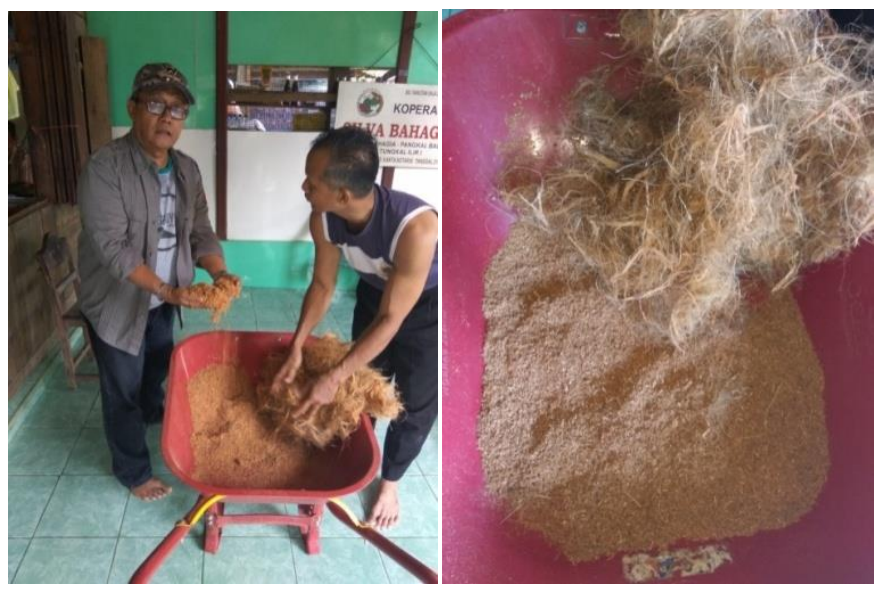

Gambar 16. Hasil Cocopeat Yang Telah Dibuat

\section{Evaluasi kegiatan}

Evaluasi dari kegiatan ini, mitra sudah cukup terampil membuat briket arang dan cocopeat. Akan tetapi perlu dilakukan pendampingan lagi untuk mempertahankan kualitas produk yang dihasilkan, kuantitas produk yang dihasilkan, dan keberlanjutan dari produk yang dihasilkan.

\section{KESIMPULAN DAN SARAN}

\section{Kesimpulan}

Kesimpulan dari kegiatan pengabdian kepada masyarakat ini antara lain :

1. Mitra telah memahami manfaat dari briket arang dan cocopeat.

2. Mitra telah menguasai teknologi sederhana dalam pembuatan briket arang dan cocopeat 


\section{Saran}

Saran dari kegiatan adalah perlu ditingkatkan lagi kualitas briket arang dan cocopeat yang dihasilkan, membantu di dalam pemasaran sehingga mitra bersemangat membuat dalam skala besar dimana akan dapat meningkatkan perekonomian dan pendapatan rumah tangga mitra.

\section{UCAPAN TERIMA KASIH}

Terima kasih kepada : Dana DIPA - PNBP Fakultas Kehutanan Universitas Jambi, Nomor : SP DIPA-042.01.2.400950/2017 Tanggal 07 Desember 2016 dan Surat Perjanjian Penugasan Dalam Rangka Pelaksanaan Pengabdian Kepada Masyarakat Nomor : 59/UN21.17/PM/2017, Tanggal 19 Mei 2017.

\section{DAFTAR PUSTAKA}

Bangun M. 2017. Komoditi Unggulan TanjabBar. Http://disbun.tanjabbar.go.id/. Diakses tanggal 6 Maret 2017.

Kemala N. 2015. Kajian Pendapatan dan Kontribusi Usahatani Kelapa (Cocos Nusifera) Terhadap Pendapatan Keluarga Petani di Kabupaten Tanjung Jabung Barat Provinsi Jambi. Jurnal Ilmiah Universitas Batanghari Volume 15 No.3 Tahun 2015 Hal 125132). 